\title{
Nauki rolnicze a wielofunkcyjny i zrównoważony rozwój rolnictwa
}

\section{Wprowadzenie}

Gospodarka w ogóle, w tym także rolnictwo podlegają ciągłym zmianom, które w pewnych okresach ulegają przyspieszeniu pod wpływem specyficznych czynników oddziałujących na tyle silnie, że możemy mówić o zmianach o charakterze rewolucyjnym. Mieliśmy więc $\mathrm{w}$ historii różne rewolucje rolnicze i przemysłowe, które prowadziły poprzez nowe czynniki do nowych sposobów gospodarowania, które na ogół cechowały się większą sprawnością, większą produktywnością i efektywnością ekonomiczną wytwarzania dóbr i usług. W rolnictwie, którego zadania skierowane są głównie na wytwarzanie żywności i surowców rolnych, procesy te doprowadziły do znacznego podniesienia produktywności ziemi i wydajności pracy rolników, co przy umiarkowanym wzroście potrzeb i popytu na żywność, zwłaszcza w krajach, które osiągnęły pewien zadowalający poziom konsumpcji, prowadzi do kurczenia się rolnictwa jako działu gospodarki narodowej i nabrzmiewania problemów wynikających z niezadowalającego wykorzystania $\mathrm{i}$ wynagrodzenia zatrudnionych $\mathrm{w}$ rolnictwie ludzi.

Zdolności wytwórcze rolnictwa, które zapewniła m.in. rozwijająca się stale agronomia, przewyższają $\mathrm{w}$ wielu krajach wysoko rozwiniętych możliwości konsumpcyjne i powodują $z$ jednej strony stałe relatywne obniżenie cen na produkty rolne, które leżą u podstaw narastania dysproporcji dochodowych rolników, z drugiej zaś działania zaradcze w postaci interwencjonizmu państwowego w mechanizmy rynkowe i poszukiwanie nowych sposobów wykorzystania zasobów produkcyjnych rolnictwa i podnoszenia dochodów rolników oraz wzrostu dobrobytu ludności wiejskiej. Jednym $z$ tych sposobów jest idea wielofunkcyjności rolnictwa, która $\mathrm{w}$ nowej odrodzonej formie, dostosowanej do współczesnych uwarunkowań, staje się wiodącą linią działań prowadzących do łagodzenia niekorzystnych skutków przekształcania rolnictwa i modernizacji wsi. 
Celem tego opracowania jest przedstawienie idei wielofunkcyjności oraz uwarunkowań jej wdrożenia. Chociaż ma ona głównie charakter ekonomiczno-społeczny, to jest jednocześnie silnie powiązana z naukami rolniczymi, w tym $\mathrm{z}$ agronomia, jako dziedziną nauk zajmujących się gospodarką na roli.

\section{Ogólne prawidłowości rozwoju}

W ciagu dwóch ostatnich stuleci główne źródła zamożności i dobrobytu ludności w gospodarkach rynkowych przesuwały się z wykorzystania zasobów naturalnych, takich jak zasoby ziemi i pracy fizycznej, najpierw na materialne zasoby wytwarzane przez człowieka, głównie pochodzenia przemysłowego, takie jak budynki, urządzenia techniczne, maszyny przemysłowe, przez środki obrotowe i zasoby finansowe, do obecnego wykorzystywania przez człowieka zasobów niematerialnych, głównie różnego rodzaju wiedzy i informacji, które mogą być ucieleśnione $w$ człowieku, $w$ organizacji lub w zasobach fizycznych. W fazie silnego uprzemysłowienia te zasoby identyfikowane są z pojęciem kapitału materialnego, ucieleśniającego różne formy postępu technicznego, organizacyjnego, technologicznego czy, co jest ważne zwłaszcza w rolnictwie i przetwórstwie rolniczym, postępu biologicznego. W fazie postindustrialnej kluczową rolę zaczyna spełniać różnego rodzaju kapitał intelektualny. Niektóre szacunki wykazują, że gdy w Stanach Zjednoczonych w latach pięćdziesiątych $80 \%$ wartości przemysłu przetwórczego występowało $\mathrm{w}$ postaci podstawowych lub przetworzonych produktów i materiałów, a $20 \%$ w postaci wiedzy i kapitału intelektualnego, to $\mathrm{w}$ latach osiemdziesiatych proporcje te odwrócily sie i wynosiły jak 30\% do 70\% [Dunning 2003]. Coraz powszechniej uświadamiany jest fakt, że wartość księgowa zasobów materialnych firm i korporacji staje się coraz to mniejszym komponentem wartości rynkowej tych firm. Trendy te odzwierciedlane są także w strukturze nakładów. W okresie 1975-1995 wydatki na różnego rodzaju prace badawcze i rozwojowe w krajach OECD wzrastały trzy razy szybciej od stopy wzrostu przemysłu przetwórczego [OECD 1997]. Procesy te, chociaż na mniejszą skalę i z pewnym opóźnieniem, zachodzą także w rolnictwie.

\section{Industrializacja i postęp rolniczy}

Rolnictwo jako dominująca wcześniej działalność gospodarcza przechodziła również przez wiele faz rozwojowych typu rewolucyjnego. Nie sięgając zbyt daleko w historię, można wskazać na zmiany, jakie w XIX wieku przyniosła rewolucja agrarna w Europie. W sferze technicznej należy wskazać cho- 
ciażby na znaczenie wprowadzenia płodozmianu, chemii rolniczej, mechanizacji, melioracji, nowych odmian roślin i ras zwierząt. Ostatnie fazy tych przemian wiążą się z industrializacją rolnictwa i modernizacją powodowaną przez postęp biologiczny. W sferze społeczno-ekonomicznej skutki rewolucji agrarnej były równie doniosłe.

W XX wieku niemal do czasów współczesnych rolnictwo rozwijało się, wykorzystując odnawialne zasoby produkcyjne i nie czyniąc wielkiego spustoszenia $\mathrm{w}$ środowisku, chociaż nierzadko realizowane dla szczytnych celów inwestycje, np. melioracyjne, prowadziły do degradacji środowiska. Industrializacja przyniosła jedynak zupełnie nowe moźliwości rozwojowe i nowe zagrożenia środowiska. Współcześnie możliwości industrialnego systemu produkcji w najbardziej rozwiniętych krajach niemal się wyczerpały, a zagrożenia modernizacji kumulują się, tworząc bariery dla dalszego rozwoju.

Uprzemysłowienie rolnictwa stworzyło szerokie możliwości wzrostu produkcji rolnej przez wytwarzanie środków produkcji wspomagających wydajność ziemi i zwierząt gospodarskich. Zastosowanie środków chemicznych, pasz przemysłowych, udoskonalonych odmian roślin i ras zwierząt oznaczało postęp agrobiologiczny i intensyfikacje gospodarczą. Wytwarzanie i wykorzystanie środków produkcji wspomagających i zastępujących siłę roboczą ludzi i zwierząt przez mechanizację i technizację usprawniło stosowanie technik wytwórczych, umożliwiło zwiększenie skali produkcji ograniczonej uprzednio zasobami pracy i ziemi, uwolniło zasoby pracy, które mogły przejść do działów poza rolnictwem i zwolniło na potrzeby produkcji żywności te zasoby, które służyły utrzymywaniu żywej siły pociagowej. Zasadniczym skutkiem industrializacji był więc wzrost wydajności czynników produkcji, produkcyjności ziemi i zwierząt oraz wydajności pracy.

Uprzemysłowienie prowadziło do zwiększenia popytu na produkty rolne i zapotrzebowania na zwalniane $\mathrm{z}$ rolnictwa zasoby pracy. $Z$ rolnictwem mogły też wiązać swoje interesy inne dziedziny gospodarki, tworząc tzw. zaopatrzeniowe, handlowe, transportowe i przetwórcze sektory agrobiznesu. Samo rolnictwo stało się też działalnością komercyjną. Powodowało to ograniczenie dotychczasowych szerokich funkcji rolnictwa na rzecz funkcji towarowych, komercyjnych. Głównym celem rolnictwa stało się osiaganie najwyższych dochodów (zysku). Do czasu, kiedy nie występowały bariery popytu, cele dochodowe rolnictwa osiaggane były przez wiekszą produkcję. Proces uprzemysłowienia i modernizacji stanowił zatem podstawę rozwojową rolnictwa. Rozwój rolnictwa napotkał jednak barierę popytu, która doprowadziła do systematycznej obniżki cen, niewydolności dochodowej rolnictwa i konieczności interwencjonizmu państwa w funkcjonowanie rynków rolnych. Modernizacja techniczna powiązana $\mathrm{z}$ postępem agronomicznym $\mathrm{i}$ genetycznym przyniosła więc konkretne efekty ekonomiczne, a równocześnie problemy ekologiczne i społeczne. 


\section{Ograniczenia i bariery rolnictwa industrialnego}

Industrializacja i modernizacja rolnictwa przez wiele lat była uznawana za proces postępowy i nowoczesny. Unowocześnienie zmieniło rolnictwo, przestawiając je ha nowe technologie, podniosło skalę ekonomicznie opłacalnej produkcji, zmieniło strukturę czynników produkcji, powodowało przebudowę struktur agrarnych, wprowadziło nową organizację procesów wytwórczych. Industrializacja i wynikające $z$ niej procesy naruszyły jednak w wielu aspektach równowagę ekologiczną. Środowisko traktowane jako dobro wolne przez wieki było ważnym czynnikiem rozwoju rolnictwa. W dobie industrializacji zaczęło być dobrem kosztownym zarówno ze względu na uświadomioną w latach siedemdziesiątych potrzebę zachowania go $\mathrm{w}$ dobrym stanie dla kolejnych pokoleń, jak też ze względu na potrzebę rekultywacji terenów zdegradowanych. Poza nabrzmiewającymi problemami ekologicznymi, najważniejszym problemem rolnictwa przemysłowego jest kwestia niezadowalającego poziomu dochodów rolniczych.

Czołowe kraje europejskie po okresie maksymalnego wykorzystania zasobów naturalnych i materialnych weszły $\mathrm{w}$ faze gospodarowania $\mathrm{w}$ rolnictwie opartego na wiedzy przy wykorzystaniu różnego rodzaju kapitału intelektualnego. Rolnictwo europejskie wychodząc $z$ fazy dużego zagęszczenia i rozdrobnienia, przeszło fazę intensyfikacji, modernizacji i specjalizacji, ciagle pogłębia skalę produkcji (koncentrację).

Uprzemysłowienie rolnictwa spowodowało radykalne zmniejszenie liczby gospodarstw i stanu zatrudnienia $\mathrm{w}$ rolnịctwie, wyrażające się nasileniem migracji i nabrzmiewaniem problemu bezrobocia. Modernizacja rolnictwa oznaczała jednocześnie zwiększenie zagrożenia dla środowiska, obniżenie jakości produktów żywnościowych i podniesienie społecznych kosztów produkcji. Produkcja rolnicza w Europie wzrastała systematycznie w latach 1950-1980, kiedy to $\mathrm{w}$ rezultacie wyczerpania się czynników rozwojowych ustabilizowała się, by w latach dziewięćdziesiatych, pod wpływem instrumentów ograniczających produkcję stosowanych przez wspólną politykę rolną przejść do fazy nawet spadkowej. W fazie industrializacji i wdrażania postępu koszty produkcji wzrastają w tempie wolniejszym niż wzrost produkcji rolniczej. Miało to miejsce do końca lat osiemdziesiątych, a na początku lat dziewięćdziesiątych koszty zaczęły wzrastać gwałtownie.

Osłabienie dynamiki wzrostu produkcji przy rosnących kosztach produkcji i subsydiowania rolnictwa czyni to rolnictwo mało efektywnym. $Z$ jednej strony, rolnictwo to zużywa zbyt wiele energii, nawozów sztucznych, środków chemicznych i pociagga zbyt wysokie nakłady finansowe, jest zbyt silnie doto- 
wane, regulowane, ograniczane i administrowane, $\mathrm{z}$ drugiej zaś strony jego zdolność produkcyjna przewyższa popyt wewnętrzny i możliwość zbytu na rynkach zagranicznych. Dodatkowo produkuje wiele niepożądanych efektów zewnętrznych w postaci zanieczyszczenia środowiska, erozji, ryzyka zagrożeń dla zdrowia itp.

Tak wykorzystany system rolnictwa europejskiego pociaga aktualnie zbyt wysokie nakłady i koszty na produkcję, która przekracza zapotrzebowanie rynkowe, która wymykając się spod kontroli i regulacji powoduje wysokie koszty społeczne i nie przezwycięża ograniczeń dochodowych rolników.

Wszystko to sprawia, iż istnieje potrzeba poszukiwania nowego systemu rolnictwa, dostosowanego do warunków i wymogów współczesności. Szanse na wykształtowanie takiego systemu daje koncepcja rolnictwa zrównoważonego oraz wielofunkcyjnego.

\section{Koncepcja rozwoju zrównoważonego}

Jedną z dróg wychodzenia $\mathrm{z}$ ograniczeń rolnictwa industrialnego jest przyjęcie i wdrożenie zasady zrównoważonego i trwałego rozwoju. Zasada ta zrodziła się $z$ potrzeby uwzględnienia $w$ procesach gospodarowania interesów obecnych i przyszłych pokoleń, zwłaszcza pod kątem zachowania walorów środowiska przyrodniczego i naturalnych zasobów produkcyjnych. Światowa Komisja ds. Środowiska Naturalnego i Rozwoju w 1987 r. uznała, że sednem koncepcji trwałego i zrównoważonego rozwoju jest „taki rozwój, który zaspokaja potrzeby obecnego pokolenia, nie ograniczając możliwości zaspokajania potrzeb przyszłych pokoleń". Zasada ta stała się konstytucyjną normą rozwoju Polski, obowiązującą we wszystkich obszarach gospodarki i wszelkich płaszczyznach strategicznego planowania rozwoju. Zasada ta wymaga więc przestrzegania równowagi w trzech podstawowych sferach: ekonomicznej, środowiskowej i społecznej. Realizacją tej zasady jest uzależnienie od konkretnych uwarunkowań i czynników rozwojowych poziomu osiągniętego rozwoju i wyznaczonych celów rozwojowych. Zasada racjonalnego gospodarowania w środowisku przyrodniczym powinna umożliwiać realizowanie celów ekonomicznych i społecznych także przy przestrzeganiu wartości kulturowych, etycznych i przestrzennych. Poszerzenie koncepcji rozwoju zrównoważonego i trwałego może być podstawą do przekształcenia tradycyjnego, trójwymiarowego ujęcia modelu rozwoju zrównoważonego (rozwój ekonomiczny, rozwój ekologiczny i rozwój społeczny) do modelu sześciowymiarowego, w którym oprócz wy- 
mienionych trzech dołączono także nowe wymiary, takie jak rozwój technologiczny, rozwój przestrzenny i rozwój etyczny [Siemiński 2001].

W 1989 r. Organizacja ds. Wyżywienia i Rolnictwa ONZ przyjęła definicję zrównoważonego rozwoju rolnictwa w brzmieniu: „Rozwój zrównoważony polega na takim wykorzystaniu i konserwacji zasobów naturalnych i takim zorientowaniu technologii i instytucji, aby osiagnnąć i utrzymać zaspokajanie ludzkich potrzeb obecnego i przyszłych pokoleñ". Taki rodzaj rozwoju (w rolnictwie, leśnictwie i rybołówstwie), konserwując glebę, zasoby wodne, rośliny oraz genetyczne zasoby zwierząt, nie degraduje środowiska, wykorzystuje odpowiednie technologie, jest żywotny ekonomicznie i akceptowany społecznie.

Rolnictwo zrównoważone jest nowoczesną koncepcją takiego programowania rozwoju, który kojarzy cele produkcyjne $\mathrm{z}$ wymaganiami środowiskowymi [Zawisza 2004]. W takim ujęciu stanowi ważną część rozwoju zrównoważonego i trwałego, który często jest określany jako ekorozwój lub przyjmuje inne pokrewne określenia. Zrównoważony rozwój jest skierowany na harmonizowanie celów społecznych, ekonomicznych i ekologicznych, prowadzących do wzrostu jakości życia $\mathrm{w}$ teraźniejszości z zachowaniem możliwości zaspokajania potrzeb ludzkich w przyszłości [Adamöwicz 2000].

Woś [1998] sprowadza pojęcie rolnictwa zrównoważonego do pięciu następujących cech:

- zasoby naturalne powinny być wykorzystywane w taki sposób, aby nie została zdławiona ich zdolność do samoodnawiania się,

- przyrost produkcji żywności może następować tylko drogą wzrostu produkcyjności zasobów, a więc przez wprowadzenie technologii, które jednocześnie chronią zasoby i zachowują ich wysoką jakość dla przyszłych pokoleń,

- rolnictwo takie wykazuje małą podatność na wahania i wstrząsy,

- zrównoważone systemy rolnicze zakładają pełną symbiozę celów produkcyjnych i ekologicznych,

- zarządzanie zasobami naturalnymi umoźliwia zaspokajanie zmieniających się potrzeb, zachowując jednocześnie wysoką jakość środowiska naturalnego i chroniąc jego zasoby.

Ogólnie zatem można stwierdzić, że rolnictwo zrównoważone jest pojęciem znacznie wykraczającym poza dotychczasowe traktowanie tego działu gospodarki. To rozszerzenie przekracza także ramy samego rolnictwa i odnoszone jest do obszarów wiejskich, a więc do dziedzin pozarolniczych na wsi. Pojęcie zrównoważonego rozwoju odnosi się w ogóle do działalności ludzkiej w każdej dziedzinie. Woś i Zegar w koncepcji zrównoważonego rozwoju obszarów wiejskich wyróżniają cztery kierunki takiego rozwoju wsi [Woś i Zegar 2002]: 
- ochrona wód, gleby i atmosfery przed zanieczyszczeniami pochodzacymi $\mathrm{z}$ rolnictwa,

- trwały i zrównoważony rozwój samego rolnictwa,

- ochrona obszarów wiejskich, w tym różnorodności biologicznej, ochrona wartości krajobrazowych i przeciwdziałanie erozji gleb,

- zachowanie niezbędnej ostrożności przy rozwoju biotechnologii i inżynierii genetycznej.

Pojęcie zrównoważonego rozwoju rolnictwa ma zatem charakter wielopłaszczyznowy i wieloaspektowy. Poza wymienionymi wyżej płaszczyznami przedmiotowymi, zjawisko to może być rozpatrywane w skali mikro-, mezoi makroekonomicznej. Występują też problemy interregionalne i globalne tego rozwoju. Funkcjonowanie i dynamika procesów rozwojowych przebiega pod wpływem zarówno samoczynnych mechanizmów rynkowych, jak też pod wpływem samoregulacji społeczności lokalnych oraz polityki regionalnej, polityki makroekonomicznej państw oraz polityk wspólnotowych Unii Europejskiej.

Szeroko koncepcję zrównoważonego rozwoju traktuje również Wilkin, wskazując na konieczność przechodzenia od polityki sektorowej do polityki zintegrowanego rozwoju obszarów wiejskich. W strategii i polityce zintegrowanego rozwoju rolnictwa i obszarów wiejskich proponuje przyjęcie pewnej hierarchii celów rozwojowych. Strategia zintegrowanego rozwoju wsi i rolnictwa w Polsce powinna być zorientowana na następujące cele [Wilkin 2003]:

- rozwój i wszechstronne wykorzystanie zasobów ludzkich istniejących na obszarach wiejskich,

- podnoszenie jakości czynnika ludzkiego, zarówno od strony człowieka jako tzw. kapitału ludzkiego, jak i od strony człowieka jako tzw. kapitału społecznego,

- instytucjonalizacja dialogu społecznego między interesariuszami zamieszkującymi obszary wiejskie, jak też sił społecznych i politycznych zajmujących sie problematyką rozwoju wsi i rolnictwa,

- stworzenie odpowiednich i wzmocnienie istniejących instytucji niezbędnych dla zintegrowanego rozwoju obszarów wiejskich,

- opracowanie odpowiedniej strategii i polityki rozwoju oraz systemu publicznego wsparcia dla rolnictwa i obszarów wiejskich,

- stworzenie mechanizmu zarządzania publicznego zasobami wiejskimi, które nie poddają się mechanizmom regulacji rynkowej, a są niezbędne dla podtrzymania zainteresowania rolników nie tylko produkcją rolna, ale także rozwojem pozaprodukcyjnych funkcji rolnictwa i obszarów wiejskich.

Jednym $z$ głównych nurtów wdrażania koncepcji zrównoważonego rozwoju wsi i rolnictwa jest wielofunkcyjność. 


\section{Wielofunkcyjność rolnictwa - istota i formy}

Jedną z podstaw, na której opiera się wizja rozwoju rolnictwa w Unii Europejskiej, która w naturalny sposób będzie kształtować sytuację polskiego rolnictwa $w$ przyszłości, jest przyjęcie europejskiego modelu rolnictwa jako długofalowej formy wytwarzania produktów rolnych i organizacji życia rolników. Jak stwierdzono w Agendzie 2000, fundamentalna różnica między europejskim modelem i tym, jaki występuje u głównych konkurentów Europy leży w wielofunkcyjnej naturze rolnictwa europejskiego, roli jaką ono odgrywa wobec gospodarki, środowiska i społeczeństwa oraz jaką może odgrywać w zachowaniu dziedzictwa wsi i zapewnieniu dochodów dla rolników [European Commission, Agenda 2000]. Rodzinne gospodarstwo rolne i wielofunkcyjność to dwie wartości, które i w przyszłości będą określać rolę i charakter rolnictwa w Europie. Wielofunkcyjność, przybierając nowe treści i formy, staje się wiodącą strategią dla rodzin wiejskich $\mathrm{w}$ warunkach kurczenia się rolnictwa i zmniejszania się jego udziału w gospodarce narodowej i gospodarce wiejskiej.

Pojęcie wielofunkcyjności jest definiowane i interpretowane na różne sposoby i odnosi się do różnych wymiarów. Dotyczy więc nie tylko sektora rolniczego jako działu produkcji i gospodarki, ale także rolnika i gospodarstwa domowego, wykracza poza sferę rolnictwa i odnosi się do gospodarki i obszarów wiejskich. Często wielofunkcyjność jest utożsamiana $\mathrm{z}$ innymi pojęciami, takimi jak dywersyfikacja (produkcji) czy wielozawodowość (wieloaktywność). Wieloaktywność jest określana jako kombinacja działalności rolniczych i nierolniczych wykonywanych przez rolników lub członków gospodarstwa domowego rolników. Innymi słowy, chodzi tu o pozyskanie nierolniczych źródeł dochodu. Dywersyfikacja odnosi się natomiast do miejsca pracy i produkcji (gospodarstwo rolne, wieś, region) i oznacza poszerzenie wachlarza wytwarzanych produktów i usług na. sprzedaż. Dywersyfikacja może być uzasadniona potrzebą lepszego wykorzystania czynników produkcji lub potrzebą ograniczenia ryzyka prowadzonej produkcji. Dywersyfikacja może być łączona z wielozawodowościq. Wielofunkcyjność wiąże się natomiast $\mathrm{z}$ różnymi funkcjami poszczególnych form aktywności, jest niejako skutkiem tej aktywności [Guy Jurand i Guido Van Huylenbroeck 2003]. Zatem różne formy rolniczej i pozarolniczej aktywności mogą być źródłem różnorodnych funkcji, które zaspokajają potrzeby społeczne. Wielofunkcyjność może wypływać zarówno $\mathrm{z}$ wytwarzania produktów o charakterze towarowym, może być skutkiem różnych form aktywności, jak też może wynikać z nietowarowej działalności rolników lub oddziaływań sektora rolniczego. 
Wielofunkcyjność może być rozpatrywana w wąskim i poszerzonym zakresie, a więc na poziomie rolnika, gospodarstwa rolnego, rolnictwa jako sektora lub działu wytwórczego czy określonego terytorium. Typowe funkcje rolnika i gospodarstwa rolnego obejmuja::

- wytwarzanie produktów żywnościowych - zdrowych, odpowiadających zapotrzebowaniom i preferencjom konsumentów, warunkom przetwarzania i dystrybucji w sposób nieszkodzący środowisku,

- przygotowanie produktów do sprzedaży i ich komercjalizację poprzez tradycyjne, ale i nowe, skrócone, zmodyfikowane kanały rynkowe bezpośrednio do sieci handlu detalicznego lub konsumentów,

- gospodarowanie w przestrzeni, wykorzystywanie zasobów przyrodniczych określonego terytorium na potrzeby gospodarcze i społeczne,

- przeciwdziałanie depopulacji,

- konserwacje oraz kształtowanie krajobrazu i udostępnianie lokalnych zasobów otwartej przestrzeni i przyrody dla społeczności lokalnej i przybyszów z zewnątrz,

- uczestniczenie w procesach rozwoju wsi poprzez kreowanie miejsc pracy w obrębie gospodarstw rolnych i poza nimi,

- tworzenie podstaw dla rozwoju pozarolniczych funkcji obszarów wiejskich, w tym budownictwa mieszkaniowego, instytucji edukacyjnych, przedsiębiorstw produkcyjnych i usługowych,

- tworzenie przestrzeni rekreacyjnej na obszarach wiejskich poprzez przystosowanie terenu i rozbudowę infrastruktury oraz bazy noclegowej i gastronomicznej dla turystyki,

- włączanie się w proces zagospodarowania odpadów i recyklingu, zgodnie $\mathrm{z}$ wymogami środowiska i zasadami życia społecznego,

- zapobieganie klęskom i katastrofom żywiołowym oraz ograniczanie ryzyka i skutków ich wystapienia poprzez tworzenie systemu ochrony przeciwpożarowej, przeciwpowodziowej i działań kontrolujących erozję,

- wkład w zachowanie dziedzictwa kulturowego i historycznego wsi.

Wiele z wymienionych wyżej funkcji przenosi się na poziom sektora rolniczego i regionu. Rolnictwo jako sektor ekonomiczny spełnia funkcje produkcyjne, środowiskowo-przestrzenne i ustugowe.

Funkcje produkcyjne obejmują wytwarzanie żywności i produktów nieżywnościowych. Na tym szczeblu ważne są zarówno parametry ilościowe, jak i jakościowe, ich zróżnicowanie oraz kwestie bezpieczeństwa żywnościowego. Funkcje produkcyjne rolnictwa podyktowane są zarówno przez wymagania konsumentów, jak też zmiany w agrobiznesie i systemach dystrybucji towarów. Funkcje produkcyjne niosą za sobą skutki społeczne związane $\mathrm{z}$ wykorzystaniem zasobów i określają miejsce i rolę rolnictwa w gospodarce narodowej. 
Funkcje środowiskowo-przestrzenne dotyczą sposobu wykorzystania środowiska, jakości krajobrazu, obecności skażeń środowiskowych, ochrony przyrody i bioróżnorodności. Zakres i sposób wykorzystania ziemi, intensywwość gospodarowania rolniczego, relacje między wykorzystaniem przestrzeni dla celów gospodarczych zwiazanych z ochroną przyrody podlegają oddziaływaniu decyzji poszczególnych podmiotów gospodarczych, jak też polityki w skali centralnej, regionalnej i lokalnej.

Funkcje ustugowe obejmują wkład rolnictwa w utrzymanie produktywności zasobów ziemi oraz bogactwa środowiska naturalnego i społecznego na potrzeby rozwoju ekonomiczno-społecznego, zatrudnienia istniejących zasobów pracy, właściwego gospodarowania odpadami, a także dla zachowania równowagi między sferą środowiskową ekonomiczną i społeczną.

Wytwarzanie pożądanych produktów przez rolników w gospodarstwach rolnych tworzy zatem wiele efektów zewnętrznych, które nie znajdują wyrazu w transakcjach rynkowych. Tak więc, obok towarów na rynek, rolnictwo wytwarza produkty o charakterze nietowarowym, które nie mają wartości rynkowej i ceny, które mają charakter dóbr publicznych. Te zewnętrzne efekty gospodarowania rolniczego mogą mieć także charakter niepożądany dla otoczenia, co ma miejsce w przypadku powodowanego przez rolnictwo skażenia środowiska przez intensywne zastosowanie nawozów sztucznych czy nieracjonalne gospodarowanie odchodami (gnojowica). Powszechnie występującą cechą wielofunkcyjności rolnictwa na wszystkich poziomach jego rozpatrywania jest „sprzężenie produkcji”, wyrażające się we wspólnym występowaniu (wytwarzaniu) towarów i produktów nietowarowych o charakterze dóbr prywatnych i dóbr publicznych [Hagedorn 2003].

Decyzje w zakresie wielofunkcyjności podejmują zarówno rolnicy, członkowie wiejskich gospodarstw domowych, kierownicy różnych przedsiębiorstw agrobiznesu i instytucji działających środowisku wiejskim, samorządy terytorialne, jak też podmioty ksztaltujące politykę rolną i rozwoju wsi. Wielofunkcyjność może być więc rozpatrywana także na różnych poziomach podejmowania decyzji dotyczących strategii, polityki i operacyjnego zarządzania.

\section{Wielofunkcyjny wymiar gospodarstwa rolnego}

Wielofunkcyjne gospodarstwo rolne jest czymś więcej niż tylko gospodarstwem wytwarzającym sprzężoną produkcję dóbr prywatnych i dóbr publicznych. W tym sensie gospodarstwo rolne zawsze miało pewien zakres wielofunkcyjności nawet w okresie niedoborów żywnościowych, gdy głównym ce- 
lem było wytworzenie produktów rolnych na rynek nawet kosztem negatywnego oddziaływania na środowisko. Wzrastającej produkcji na rynek towarzyszyły często negatywne efekty zewnętrzne, wynikające $z$ nadmiernej intensyfikacji naruszającej bezwiednie równowagę środowiska przyrodniczego.

Przejście na pozycje gospodarstwa wielofunkcyjnego oznacza świadome przyjęcie i przestrzeganie przez rolnika pewnych wartości i zasad w prowadzeniu gospodarstwa rolnego. Te zasady i wartości musza być realizowane w trzech wymiarach (płaszczyznach) funkcjonowania gospodarstwa rolnego [Douwe Jan, Van der Ploeg, i Dirk Roep 2003]:

- wykorzystania zasobów,

- wytwarzania i udostępniania żywności,

- kształtowania obszaru wsi (rys. 1).

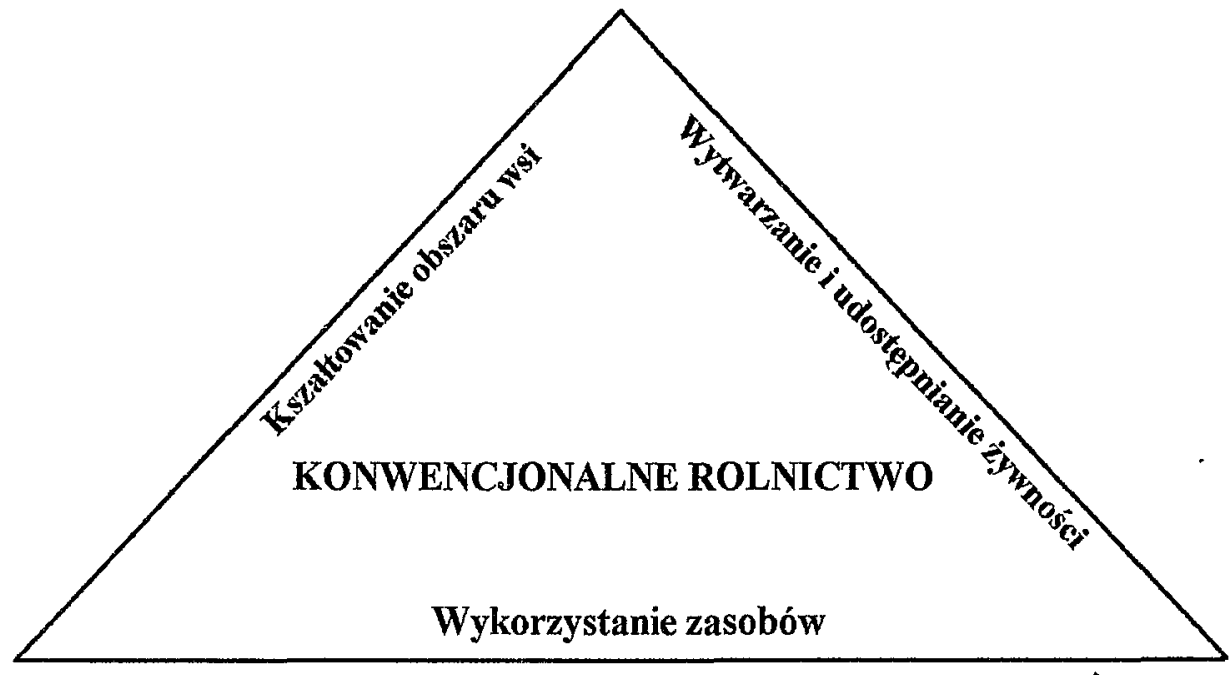

\section{Rysunek 1}

Trzy wymiary funkcjonowania gospodarstwa rolnego prowadzącego konwencjonainą produkcję rolniczą

Żródło: Zaadaptowane przy wykorzystaniu pracy Deuve Jan, Van der Ploeg...

Gospodarstwo rolne może być tu przedstawione w postaci trójkąta. Podstawa trójkąta reprezentuje wymiar organizacyjny, w którym gospodarstwo łączy własne zasoby pracy, ziemi, kapitału i wiedzy dla podjęcia procesu produkcji. Drugi bok reprezentuje wytwarzanie surowców i produktów rolno-spożywczych i wprowadzenie ich do kanałów rynkowych celem udostępnienia dla przetwórstwa, handlu i ostatecznej konsumpcji. Trzeci bok to funkcjonowanie gospodarstwa rolnego $\mathrm{w}$ środowisku wiejskim, polegające na wykorzystywaniu zasobów naturalnych, społecznych i kulturowych oraz oddziaływaniu na środowisko wiejskie. Każda zmiana w jednej płaszczyźnie wpływa na inne. 
Każda zmiana w funkcjonowaniu gospodarstwa wywołuje reakcje w każdej $z$ trzech płaszczyzn. Przejście od monofunkcyjności do wielofunkcyjności gospodarstwa rolnego $\mathrm{w}$ każdym $\mathrm{z}$ trzech wymienionych wymiarów oznacza przyjęcie pewnej strategii. W dążeniu do osiągnięcia wielofunkcyjności można wyróżnić strategie:

- reorganizacji zasobów,

- pogłębiania działalności,

- poszerzania działalności.

Każda strategia może być realizowana przez wprowadzenie wielu różnych form działalności wyszczególnionych na rysunku 2 i w tabeli 2.

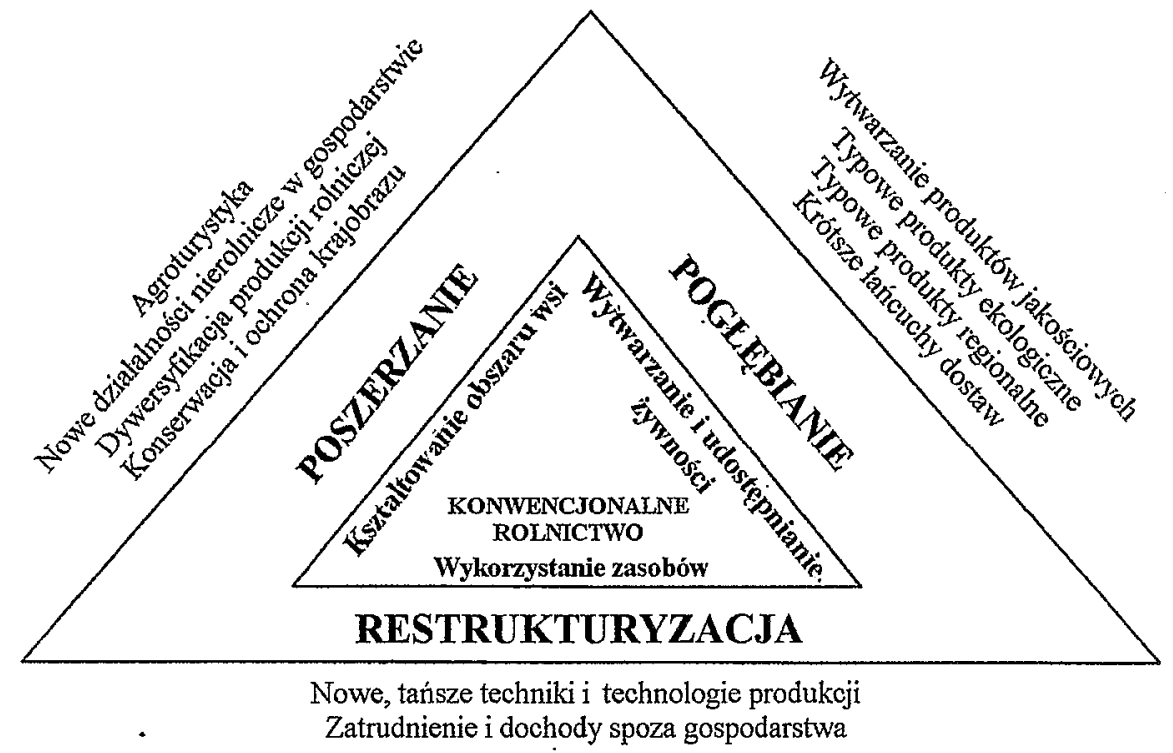

\section{Rysunek 2}

Nowe kierunki i formy aktywności gospodarstw rolnych w ramach strategii wielofunkcyjności

Żródło: jak wyżej.

\section{Strategie i działania w ramach wielofunkcyjności}

W wymiarze mobilizacji zasobów produkcyjnych przy przejściu do wielofunkcyjności mamy do czynienia ze strategią reorganizacji zasobów produkcyjnych. Najprostszą i tradycyjną formą jest wykorzystanie zasobów pracy na zewnątrz gospodarstwa i pozyskanie dochodów $z$ dwuzawodowości lub wieloaktywności. Wieloaktywność oznacza łączenie dochodów rolniczych $z$ dochodami spoza gospodarstwa rolnego. Racjonalne wykorzystanie zasobów pracy może 
Tabela 1

Wymiar, strategie i działalności w ramach wielofunkcyjności gospodarstw rolnych

\begin{tabular}{|c|c|c|}
\hline $\begin{array}{l}\text { Wymiar funkcji gospodar- } \\
\text { stwa rolnego }\end{array}$ & $\begin{array}{l}\text { Strategia rozwoju } \\
\text { wielofunkcyjności }\end{array}$ & $\begin{array}{l}\text { Działalności w ramach wybranych } \\
\text { funkcji }\end{array}$ \\
\hline $\begin{array}{l}\text { Mobilizacja (organizacja } \\
\text { i wykorzystanie) zasobów }\end{array}$ & $\frac{\text { Reorganizacja }}{\text { (zasobów) }}$ & $\begin{array}{l}\text { Zatrudnienie i dochody poza gospo- } \\
\text { darstwem } \\
\text { Nowe, tańsze techniki i technologie } \\
\text { produkcji }\end{array}$ \\
\hline $\begin{array}{l}\text { Wytwarzanie } \\
\text { i udostępnianie żywności }\end{array}$ & $\begin{array}{l}\text { Pogłebianie } \\
\text { (zmiany i doskona- } \\
\text { lenie działalności) }\end{array}$ & $\begin{array}{l}\text { Wytwarzanie produktów o wysokiej } \\
\text { jakości } \\
\text { Rolnictwo ekologiczne } \\
\text { Typowe produkty ekologiczne } \\
\text { i z produkcji zintegrowanej } \\
\text { Typowe produkty regionalne } \\
\text { Krótsze lańcuchy dostaw }\end{array}$ \\
\hline $\begin{array}{l}\text { Kształtowanie obszaru } \\
\text { wsi }\end{array}$ & $\begin{array}{l}\text { Poszerzanie (po- } \\
\text { dejmowanie dodat- } \\
\text { kowych działalno- } \\
\text { ści) }\end{array}$ & $\begin{array}{l}\text { Agroturystyka } \\
\text { Nowe działalności nierolnicze } \\
\text { w gospodarstwie } \\
\text { Dywersyfikacja produkcji } \\
\text { Konserwacja i ochrona krajobrazu }\end{array}$ \\
\hline
\end{tabular}

Źródło: Zaadaptowane opracowanie przy wykorzystaniu ksiażki: Guido van Huylenbroeck, Guy Durand (Ed.): Multifunctional Agriculture; A New paradigm for Europe, Agriculture and Rural Development, Ashagate 2002.

wiązać się $\mathrm{z}$ reorganizacją procesów produkcji $\mathrm{i}$ lepszym sposobem powiązania $\mathrm{z}$ rynkiem oraz ze zmniejszeniem intensywności zatrudnienia $w$ gospodarstwie zarówno przez samego rolnika, jak i członków jego rodziny. Gospodarstwo rolne staje się w tym wymiarze tylko jednym ze sposobów pozyskiwania dochodów przez gospodarstwo domowe, które staje się głównym podmiotem gospodarowania zasobami. Gospodarstwo rolne staje się podporządkowane interesom i celom gospodarstwa domowego.

Restrukturyzacja zasobów oznacza także inne umocowanie gospodarstwa rolnego w środowisku rynku pracy i lokalnych stosunków ekonomiczno-społecznych. Członkowie gospodarstwa dążą do zdobycia nowych kwalifikacji i umiejętności poszerzających ich zawodowe kompetencje i możliwości. Następuje często reorganizacja ról i funkcji, zwłaszcza w odniesieniu do kobiet, dzieci i osób emerytowanych. W gospodarstwach takich może występować inne ustosunkowanie się do źródeł nakładów, które będą wykorzystane bardziej ekonomicznie. Może nastąić świadome ograniczanie zakupów zewnętrznych i lepsze wykorzystanie zasobów wewnętrznych (pastwisk, nawozów organicznych, własnych oszczędności, własnej pracy) zastępujących usługi zewnętrzne. 
Takie działania wywierają wpływ na lokalne środowisko przyrodnicze. Reorganizacja zasobów przynosi wymierne efekty ekonomiczne, $z$ jednej strony dodatkowe dochody zewnętrzne $z$ drugiej zaś - redukcje kosztów.

Wielofunkcyjność w sferze wytwarzania i udostępniania żywności oznacza pogłębianie istniejącej działalności rolniczej wewnątrz gospodarstwa. Głównym celem jest tu poszukiwanie nowej wartości i dodawanie wartości do produkcji rolniczej. Osiagga się to przez wyższe ceny za specjalne przygotowane i dostarczone do konsumentów produkty. Przykładem może być tu typowa produkcja metodami ekologicznymi, wstępne i całkowite przetworzenie surowców w gospodarstwie rolnym, wytwarzanie typowych, wysokiej jakości produktów lokalnych czy regionalnych, sprzedaż bezpośrednio konsumentowi lub odbiorcom finalnym (supermarketom).

Rozwój wielofunkcyjności wiąże się z oddziaływaniem gospodarstwa rolnego na otoczenie zewnętrzne, a więc na środowisko lokalne wsi, gminy, powiatu (mikro- i mezoregionu). Kształtowanie obszaru wsi realizowane jest przez strategie poszerzania działalności $\mathrm{w}$ środowisku wiejskim przez takie działania jak oferowanie ushug agroturystycznych, które lepiej pozwalają wykorzystać zasoby pracy i budynki oraz majątek gospodarstwa. Wchodzą tu też $\mathrm{i}$ inne, nowe działalności nierolnicze na teren gospodarstwa, takie jak produkcja energii ze źródeł biologicznych, prowadzenie warsztatów naprawczych, magazynów, punktów sprzedaży itp. Istotną przeszkodą dywersyfikacji może być niska ekonomiczna efektywność tych działań. Funkcje gospodarstwa rolnego rozszerzają się także na środowisko przyrodnicze, krajobraz, ogólną estetykę i kulture wiejska. Kształtowanie walorów środowiska, zachowanie pięknego krajobrazu, utrzymanie cennych obiektów przyrody i kultury wsi też wynika $\mathrm{z}$ zachowania się gospodarstw rolnych. Działania te maja przynieść dochód bądź $\mathrm{z}$ bezpośrednich transakcji rynkowych, bądź $\mathrm{z}$ różnych form wsparcia ze strony polityki rolnej i rozwoju wsi.

Elementem tej strategii może być dywersyfikacja działalności produkcyjnej przez podejmowanie hodowli pszczół i produkcji miodu, grzybów, ryb, roślin aromatycznych, drobnych zwierzat domowych itp. W strategii ukierunkowanej na środowisko wiejskie ważną rolę spełnia dostosowanie praktyk rolniczych do wymogów ochrony środowiska i konserwacji krajobrazu oraz społecznych stosunków w środowisku lokalnym.

\section{Efekty i korzyści wielofunkcyjności}

Wielofunkcyjność gospodarstw rolnych prowadzi do bardziej zrównoważonego rolnictwa. Stosowanie strategii reorganizacji zasobów, pogłębiania i poszerzania działalności prowadzi do przekształcenia gospodarstwa rolnego 
w przedsiębiorstwo wielofunkcyjne, dostarczające szeroką gamę produktów i usług zarówno rynkowych (PR), jak i nierynkowych (PN). Wielofunkcyjność może się rozwijać, jeśli przynosi korzyści dla gospodarstw rolnych, jak i korzyści zewnętrzne (społeczne).

Korzyści wynikające $\mathrm{z}$ wielofunkcyjności rozkładają się na sferę gospodarstwa rolnego i na jego otoczenie. Zestawienie podziału tych korzyści z podziałem efektów na efekty towarowe (rynkowe) i nietowarowe (nierynkowe) daje możliwość wyodrębnienia czterech grup korzyści w postaci [Bellerti, Brunori, Marescotti, Rossi 2003]:

1) ekonomicznych efektów gospodarstwa rolnego,

2) ekonomicznych efektów gospodarki lokalnej,

3) socjalnych efektów gospodarstwa domowego,

4) efektów zrównoważonego rozwoju wsi.

Rodzaje tych efektów przedstawiono w tabeli 2.

Tabela 2

Klasyfikacja efektów wielofunkcyjności gospodarstwa rolnego

\begin{tabular}{|c|c|c|}
\hline Produkty & Efekty wewnętrzne (EW) & Efekty zewnętrzne (EZ) \\
\hline $\begin{array}{l}\text { Towarowe } \\
\text { (PR) }\end{array}$ & $\begin{array}{l}\text { 1. Ekonomiczne efekty gospo- } \\
\text { darstwa rolnego } \\
\text { - wyższe ceny } \\
\text { - większy udział rolnika w war- } \\
\text { tości dodanej } \\
\text { - wyższe dochody } \\
\text { - lepsze wykorzystanie zatrud- } \\
\text { nienia w gospodarstwie } \\
\text { - większa stabilność dochodów }\end{array}$ & $\begin{array}{l}\text { 2. Ekonomiczne efekty gospodarki } \\
\text { lokalnej } \\
\text { - szersza oferta produktów } \\
\text { - podnoszenie standardów jako- } \\
\text { ściowych } \\
\text { - większa liczba turystów } \\
\text { - wyższe ceny ziemi } \\
\text { - lepsza reputacja terenu } \\
\text { - nowe możliwości zatrudnienia }\end{array}$ \\
\hline $\begin{array}{l}\text { Nietowarowe } \\
\text { (PN) }\end{array}$ & $\begin{array}{l}\text { 3. Socjalne efekty gospodarstwa } \\
\text { domowego } \\
\text { - wyższa jakość zasobów pracy } \\
\text { (kapitału ludzkiego) } \\
\text { - lepsza jakość pracy } \\
\text { - lepsza wycena zasobów pracy } \\
\text { kobiet, młodzieży i ludzi sta- } \\
\text { rych } \\
\text { - zmniejszenie napięć i stresów }\end{array}$ & $\begin{array}{l}\text { 4. Efekty zrównoważonego roz- } \\
\text { woju wsi } \\
\text { - rozwój osadnictwa wiejskiego } \\
\text { - podnoszenie jakości towarów } \\
\text { i warunków życia } \\
\text { - poprawa walorów krajobrazu } \\
\text { - ochrona i poprawa walorów } \\
\text { środowiska } \\
\text { - zwiększenie bioróżnorodności } \\
\text { - poprawa dobrostanu zwierząt } \\
\text { - zachowanie walorów kulturowych } \\
\text { - powiększenie kapitału społecz- } \\
\text { nego } \\
\text { - akumulacja wiedzy, kultury } \\
\text { i przedsiębjorczości }\end{array}$ \\
\hline
\end{tabular}

Źródło: Opracowanie własne na podstawie: Belleti, Brunori, Marescotti, Rossi 2003. 
Do najważniejszych efektów wewnętrznych wielofunkcyjności gospodarstwa rolnego można zaliczyć możliwość uzyskania wyższych cen ze sprzedaży produktów ekologicznych i wyższych dochodów, co wynika także z możliwości lepszego wykorzystania zasobów pracy i innych czynników produkcji.

Wśród efektów zewnętrznych należy zwrócić uwagę na szerszą ofertę produkcyjną danego regionu, poprawę jakości oferowanych produktów, większą dostępność dla turystów i inwestorów zewnętrznych, co powiększa popyt na ziemię i podnosi jej ceny. Poprawa reputacji terenu może przynieść nowe możliwości zatrudnienia i rozwoju.

Efekty nietowarowe rozkładaja się na gospodarstwa rolne i sfere publiczna. Przeważnie dotyczy to efektów podnoszenia jakości zasobów ludzkich i docenienia wkładu pracy kobiet, dzieci i pozostałych członków gospodarstwa domowego. Te efekty dotyczą bardziej gospodarstwa domowego niż gospodarstwa rolnego, przyczyniając się do podnoszenia jakości życia we wszystkich gospodarstwach domowych.

Czwarta grupa efektów dotyczy ogólnego wpływu wielofunkcyjności gospodarstw rolnych i rolnictwa na zrównoważony rozwój wsi i rolnictwa. Efekty mające głównie charakter dóbr publicznych rozkładają się zarówno na sferę zasobów materialnych, zasobów ludzkich, jak i środowiskowych oraz kulturowych. Efekty te są związane z poszczególnymi produktami materialnymi i usługami bądź mają charakter oddziaływania pośredniego na przedsiębiorczość i efektywność danego środowiska wiejskiego. Między tymi czterema grupami efektów istnieją wzajemne związki i interrelacje.

\section{Rola nauk rolniczych w rozwoju rolnictwa wielofunkcyjnego}

Poszukiwanie nowego modelu rolnictwa wielofunkcyjnego, rozwijającego się w sposób trwały i zrównoważony, wymaga wsparcia ze strony nauki, w tym ważną rolę mogą spełniać nauki rolnicze. W okresie po II wojnie światowej rozwój nauki i technologii przyczynił się do ekspansji i sukcesu, jakie osiągnęło rolnictwo europejskie. Wykorzystanie osiagnięć naukowych w praktyce prowadziło do racjonalizacji i modernizacji rolnictwa. Dziś nowe uwarunkowania ekonomiczne, środowiskowe i społeczne otwierają nowe wyzwania. Współcześnie trudność osiagnięcia efektywności ekonomicznej oznacza wątpliwość co do racjonalności dotychczasowej polityki rolnej. Nową perspektywę wobec koncepcji racjonalności stwarza koncepcja zrównoważonego i trwałego rozwoju, która pojawiła się przed kilkoma dekadami, a także koncepcje rozu- 
mianej po nowemu wielofunkcyjności. Jak już mówiliśmy wcześniej, podstawą koncepcji zrównoważonego rozwoju jest integracja celów ekonomicznych, środowiskowych i społecznych. Koncepcja rozwoju zrównoważonego stwarza nowe wyzwanie dla nauki. Nauka powinna kształtować podstawy do tego, by zasady zrównoważonego i wielofunkcyjnego rozwoju mogły być wdrażane do praktyki rolniczej. Pozostaje pytanie: czy dzisiaj nauki rolnicze są $\mathrm{w}$ stanie przyczynić się do rozwiązania aktualnych problemów, przed jakimi staje rolnictwo? Pytanie to ma zapewne charakter retoryczny. Aby to mogło się stać, niezbędne sąjednak przewartościowania w samej nauce. Takie przewartościowania powinny dotyczyć kwestii instytucjonalnych, przedmiotowych, metodologicznych, a nawet epistemologicznych. Wyzwania, jakie mogą wystapić, można ująć co najmniej w trzech następujących grupach:

1) jak poradzić sobie $\mathrm{z}$ różnymi zmieniającymi się celami rolnictwa,

2) jak rozwiązywać problemy złożone w całej ich kompleksowości,

3) jak wdrażać do praktyki osiągnięcia nauki.

Sprostanie tym wyzwaniom wskazuje na potrzebę podejścia multidyscyplinarnego, wielofunkcyjnego i zintegrowanego (interdyscyplinarnego), które to cechy wydają się wyznaczać nowy paradygmat rozwoju rolnictwa.

W klasycznych naukach rolniczych przedmiotem badań są procesy życiowe organizmów żywych w kontekście ich wykorzystania w procesach produkcji rolniczej. Badaniom tego typu przyświecają potrzeby racjonalizacji tych procesów. Racjonalność produkcji wyznacza jej efektywność ekonomiczną.

Integracja celów ekonomicznych, środowiskowych i społecznych może przebiegać $w$ różny sposób. Wydaje się, że integracja tych różnych celów będzie wymagać nowego podejścia i nowych metod skierowanych na wypracowanie bardziej uniwersalnej wiedzy i zintegrowanych metod działania. Osadzenie badań rolniczych w kontekście ekonomicznym, ekologicznym i społecznym wymaga interdyscyplinarnego podejścia i zintegrowanej wiedzy nauk rolniczych, środowiskowych i społecznych. Prowadzenie badań podstawowych i wdrażanie wyników badań do praktyki oraz ksztaltowanie procesów technologicznych $\mathrm{w}$ tak szeroko zakreślonym polu badawczym nie jest oczywiście proste i łatwe, ale praktycznie proces ten aktualnie ma miejsce w praktyce.

W tabeli 3 umieszczono wiele rodzajów nauk rolniczych o różnym stopniu zintegrowania według dwóch kryteriów - zakresu przedmiotowego badań i podejścia naukowego (liczby dyscyplin zajmujących się danym przedmiotem).

Dwa wymiary tej macierzy określają $z$ jednej strony relacje między dyscyplinami, z drugiej zaś stopień złożoności (zintegrowania) przedmiotu badań. W klasycznych naukach rolniczych przedmiotem badan sa procesy życiowe organizmów żywych w kontekście wykorzystania ich w procesach produkcji rolniczej. W odróżnieniu od monopodejścia klasycznych, pojedynczych dyscyplin 


\section{Tabela 3}

Integracja nauk rolniczych w przedziale od klasycznego podejścia jednodyscyplinarnego do przyszłościowego podejścia systemowego

\begin{tabular}{|l|l|c|c|c|c|}
\hline \multirow{2}{*}{ Lp. } & $\begin{array}{l}\text { Przedmiot zaintere- } \\
\text { sowania nauki }\end{array}$ & \multicolumn{4}{|c|}{ Dyscyplinarność } \\
\cline { 2 - 6 } & Organizmy żywe & $\begin{array}{c}\text { (1) Mono } \\
\text { klasyczne }\end{array}$ & (2) Multi & (3) Inter & (4) Trans \\
\hline 1 & Pole - uprawa & 2.1 & 2.2 & 1.3 & 1.4 \\
\hline 3 & Gospodarstwa rolne & 3.1 & 3.2 & 3.3 & 2.4 \\
\hline 4 & Region & 4.1 & 4.2 & 4.3 & $\begin{array}{c}\text { 4.4 Teoria } \\
\text { agrosystemu }\end{array}$ \\
\hline
\end{tabular}

Źródło: Schakel 2003.

naukowych, badanie systemów rolniczych w układzie regionalnym wymaga podejścia interdyscyplinarnego. Interdyscyplinarność oznacza integrację nie tylko przedmiotowa, ale także metodologiczną $i$ wypracowanie nowej strategii i badań obejmującej aspekty instytucjonalne, metodyczne i teoretyczne.

Praktyka wykazuje, że procesy integracyjne w nauce zostały znacznie zaawansowane, dochodząc niekiedy do poziomu transdyscyplinarności. Przy badaniu organizmów żywych przykładem może być teoria ekologii produkcji (1.4), w przypadku badań produkcji polowej mamy do czynienia $z$ agroekologia (2.4), w przypadku badań gospodarstw rolnych przykładem transdyscyplinarności są badania systemów produkcyjnych (3.4), a w przypadku regionu można mówić o teorii agrosystemów (4.4). Interdyscyplinarność wdrażana jest dość powszechnie na różnych poziomach przez zastosowanie komputerów i metod matematycznych. Przykładem moga tu być modele symulacyjne struktury upraw (1.3), ekotechnologii (2.3), modele wspierania decyzji (3.3) czy metody, techniki i scenariusze optymalizacji rolnictwa $w$ regionie (4.4).

Kryzys rolnictwa przemysłowego i potrzeba kształtowania nowego modelu rolnictwa wielofunkcyjnego w ramach koncepcji rozwoju trwałego i zrównoważonego odnosi się przede wszystkim do krajów najbardziej rozwiniętych, dysponujących wysokoprodukcyjnym, nowoczesnym rolnictwem. Nasuwa się pytanie, czy to wszystko odnosi się do Polski, w której procesy uprzemysłowienia $\mathrm{i}$ modernizacji rolnictwa nie zostały tak mocno zaawansowane, a w okresie transformacji nawet się cofnęły. Polskie rolnictwo nie wykorzystało z pewnością w pełni potencjału tkwiącego w ,przemysłowym" modelu rozwojowym i mogłoby osiagnąc w ramach tej koncepcji znaczne sukcesy. Potrzeba przechodzenia na tory rolnictwa wielofunkcyjnego i zrównoważonego wynika jednak $\mathrm{z}$ dwóch ważnych powodów. Jednym jest to, że przyjmując tę nową koncepcje możemy uniknąć wielu negatywnych zjawisk, które wystąpiły 
w krajach wysoko intensywnego rolnictwa. Powodem drugim jest to, że polskie rolnictwo zostało włączone w jednolity system wspólnej polityki rolnej Unii Europejskiej, która ewoluuje $\mathrm{w}$ kierunku wskazanym przez zasady rolnictwa wielofunkcyjnego. Włączenie się $\mathrm{w}$ ten proces daje szansę nadrobienia pewnych opóźnień rozwojowych i wzrostu konkurencyjności. Proces ten wymaga odpowiedniego wsparcia ze strony nauki, w tym nauk rolniczych, w których agronomia odgrywa kluczową rolę.

\section{Literatura}

ADAMOWICZ M., 2000: Rola polityki agrarnej w zrównoważonym rozwoju obszarów wiejskich. Rocz. Nauk. Roln. Seria II, 1, 69-81.

ADAMOWICZ M., 2003: Perspektywiczne kierunki ewolucji wspólnej polityki rolnej. Roczniki Nauk Rolniczych, Seria G-Ekonomika Rolnictwa, Tom 90, zeszyt 1, s. 18-31.

BELLETI G., BRUNORI G., MARESCOTTI A., ROSSI A., 2003: Multifunctionality and rural development - a multilevel approach. In: Multifunctional Agriculture. A New Paradigm for European Agriculture and Rural Development, Ashgate.

DURAND GUY, GUIDO Van HUYLENBROECK, 2003: Multifunctionality and rural development: a general framework. In: Multifunctional Agriculture. A New Paradigm for European Agriculture and Rural Development, Ashgate, s. 1-16.

DOUVE JAN van der PLOEG, DIRK ROEP, 2003: Multifunctionality and rural development: the actual situation in Europe. In: Multifunctional Agriculture. A New Paradigm for European Agriculture and Rural Development, Ashgate, s. 37-53.

DUNNING J.H. (red.), 2003: Regions, Globalization and the Knowledge-Based Economy, Oxford.

European Commission, 1999: Agenda 2000. Agriculture environmemnt, rural development. Facts and Figures. A challenge for Ảgriculture, Luksemburg.

European Commission, 1988: The Future of Rural Country Side, COM (88), 501 find.

HAGEDORN K., 2003: Rethinking the theory of agricultural change in an institution of sustainability perspective. In: Importance of Policies and Institutions for Agriculture Prof. dr inż. Laurent Martens, Academic Press Liber Amicornm, s. 33-56.

KŁODZIŃSKI M., 1997: Istota wielofunkcyjnego rozwoju obszarów wiejskich. W: Ekonomiczne i społeczne uwarunkowania i możliwości wielofunkcyjnego rozwoju wsi w Polsce, Warszawa, s. 41.

OECD, 2001: Multifunctionality Towards an Analytical Framework, OECD, Paris.

PETIT M. 2003: European policies and world market liberalization. In: Importance of Policies and Institutions for agriculture, Academic Press, pp 79-100.

SIEMIŃSKI J.L, 2001: Koncepcje "susstainable development" rozwoju zrównoważonego i trwałego obszarów wiejskich w Polsce (szanse i możliwości). Referat na konferencji IUNG w Puławach.

SCHOKEL J., 2003: Transdisciplinarity and pluractivity or the consquences of multifunctionality for agricultural scence and education. In: Multifunctional and Agriculture. A New Paradigm for European Agriculture and Development, Ashgate, s. 225-235. 
WILKIN J., (red), 2003: Podstawy strategii zintegrowanego rozwoju rolnictwa i obszarów wiejskich w Polsce, Uniwersytet Warszawski, Wydział Nauk Ekonomicznych, Warszawa.

WOŚ A., 1998: Rolnictwo zrównoważone. Encyklopedia agrobiznesu, Fundacja Innowacja, Warszawa, s. 735.

WOŚ A., ZEGAR S. 2002: Rolnictwo społecznie zrównoważone. IERGŻ, Warszawa.

ZAWISZA S., (red.), 2004: Zarządzanie zrównoważonym rozwojem obszarów wiejskich, Wydaw. Uczelniane ATR w Bydgoszczy.

\title{
Agricultural Sciences and the Multifunctional and Sustainable Development of Agriculture
}

\begin{abstract}
The aim of the paper is discussing the multifunctionality of agriculture and its links with sustainable development as well as the role of agricultural sciences in implementation of those ideas. The industrialization and modernisation of agriculture and their limitations were presented on the ground of general description of development rules. The idea of multifunctionality and its forms, multifunctional dimension of agricultural farms, multifunctional strategies and their effects were analysed. Proposals for the role of agricultural sciences in multifunctional and sustainable development of agriculture in Poland were suggested.
\end{abstract}

